\title{
GROWING SIGNIFICANCE OF BAUXITES
}

by

\section{György Bárdossy}

\begin{abstract}
Aluminium, one of the more widely-used metals in modern technology, is mainly obtained from bauxite. This summary article traces the formation of bauxites through geological time and different geomorphological settings, and proposes a new theory to account for the varying intensity of bauxite formation.
\end{abstract}

\section{Introduction}

Bauxite, a sedimentary rock enriched in aluminium hydroxide minerals, is the most important raw material of aluminium, and is therefore highly important economically. $96 \%$ of all alumina produced in the world comes from bauxite, and only $4 \%$ from nephelinite and alunite. For the last 30 years, world-wide aluminium consumption has been growing at a yearly rate of $8-10 \%$, and the production of primary aluminium reached 14.2 million tons by 1977 .

This quickly growing demand has given rise to a continuing search for bauxite all over the world; systematic prospecting of large territories has resulted in a rapid increase of known bauxite reserves (from 120 million metric tons in 1900, to 1815 in 1953, and 21600 in 1974). A recent estimation (Lotze, 1978) gives the following values:

\begin{tabular}{|c|c|}
\hline Continent & Reserves* \\
\hline Africa & (in million metric tons) \\
\hline America & 11345 \\
\hline Asia & 6585 \\
\hline Australia & 6025 \\
\hline Europe & 1470 \\
\hline World Total & $38 \quad 225$ \\
\hline
\end{tabular}

The largest new bauxite discoveries since World War II have been in Australia, Jamaica, Brazil, Surinam, India, and Venezuela. During the period spanning the beginning of bauxite mining (at the end of the last century) until 1977, around 1079 million tons of bauxite had been exploited.

\section{Classification}

Bauxite geologists commonly refer to the following classification, based on depositional features:

1. Lateritic bauxite deposits: underlain by alumosilicate rocks, these bauxites are the products of in situ tropical weathering. They can be further subdivided in various ways (see Valeton, 1972).

2. Karst bauxite deposits: these cover the uneven, karstified surface of limestones and dolomites. There is an unconformity or at least a disconformity between the deposit and the bedrock. Five subtypes can be distinguished, as shown in Figure 1.

3. Tichwin-type deposits: these overlie unconformably the surface of different alumosilicate rocks but have no direct genetic relation with them. Their material was transported from elsewhere.

$85 \%$ of the world bauxite tonnage belongs to the Lateritic bauxite deposits, $14 \%$ to the Karstic and only $1 \%$ to the Tichwin-type ones. The term "laterite" in its broadest meaning includes all products of lateritization, that is of wet tropical weathering. Most abundant are the clay laterites, but lateritic iron ores are also common. Lateritic manganese and nickel ores may occur but rarely. Lateritic bauxites are the Al-rich end members of this broad petrographic unit.
Main types of Karst-bauxite deposits

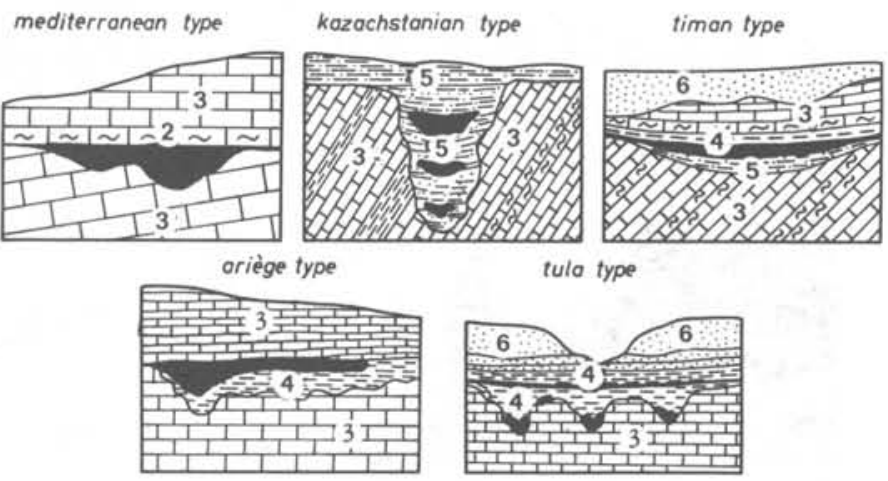

Figure 1. 1. (black) bauxite and bauxitic clay 2. marl 3. limestone or dolostone 4. clay or claystone 5. sandy clay 6. sand

\section{Distribution in Space and Time}

Bauxites are not known to appear all over the world. The biggest Lateritic bauxite areas are on the Guyana Shield, in West Africa, India and North Australia. The Karst bauxite belts are located to the north of the main Lateritic bauxite areas. There are only a few Karst bauxite deposits to the south of the Equator (Solomon, Loyalty, Tonga and Fiji Islands). Most of the Karst bauxites are concentrated in the Caribbean (Jamaica) and in the Mediterranean bauxite belt (Greece, Hungary and Yugoslavia). The Tichwin-type deposits are most common on the Russian Platform, in the Ural Mountains and in China.

There is a close relationship between the geographic distribution of the deposits and their geotectonic position (see Table 1).

Table 1

Distribution of Bauxite Tonnages on First Order Geotectonic Units

\begin{tabular}{lccc}
\hline Tectonic units & $\begin{array}{l}\text { Lateritic } \\
\text { bauxites } \\
\text { (in \%) }\end{array}$ & $\begin{array}{l}\text { Karst } \\
\text { bauxites }\end{array}$ & $\begin{array}{c}\text { Tichwin- } \\
\text { (in \%) } \\
\text { bauxites } \\
\text { (in \%) }\end{array}$ \\
\hline Continental platforms & 96 & 8 & 100 \\
Orogenic belts & 3 & 92 & - \\
Oceanic basin areas & 1 & - & -- \\
\hline
\end{tabular}

*These figures would be termed "total resources" in North American terminology; hence, total reserves would be close to 27000 million metric tons (U.S. Bureau of Mines, 1979, Mineral Commodity Summaries, p. 19). 
As might be expected, most Lateritic bauxites are found on tectonically quiet continental platform areas, whereas Karst bauxites are situated generally in orogenic belts. In oceanic basins, no bauxites were formed except on some volcanic islands (such as Hawaii).

The oldest known bauxites are about $3100 \mathrm{Ma}$. They are slightly metamorphosed Lateritic bauxites from Swaziland, South Africa (Hunter, 1962). Younger, small occurrences of weakly metamorphosed bauxites, grading into emeries have been described from other parts of South Africa (Coetzee, 1940) and from the Aldan region in Siberia (Sidorenko and Teniakov, 1976), ranging in age from 600 to $900 \mathrm{Ma}$.

In the Devonian of the Timan Mountains, U.S.S.R., Kirpal and Teniakov (1978) reported redeposited lateritic bauxites, a transitional type between Lateritic and Karst bauxites. During the Lower Carboniferous major Lateritic bauxite deposits formed at Bielgorod, U.S.S.R., but only minor bauxites formed during the Permian, Triassic and Jurassic. Structural and geomorphological evidence indicates that the formation of the big Lateritic bauxite deposits in West Africa, India and Australia began in the Upper Cretaceous and reached its peak intensity during the Paleocene and Eocene. The bauxites of the Guyana Shield have well defined Eocene, Oligocene and Miocene ages (Aleva, 1975, and Greig, 1977). Although the formation of lateritic bauxites continues today, there is much controversy among researchers about the rate and consequent intensity of the process.

The oldest Karst bauxites, of Late Proterozoic to Early Cambrian age, are found in the Eastern Sayan Mountains, U.S.S.R. (Michailov, 1977), but the oldest Karst bauxite formation of economic significance occurred during the Devonian, when large deposits were formed in the Ural, Timan and Altai Mountains of U.S.S.R. More Karst-type deposits were formed during the Carboniferous in China and in the Timan Mountains, but relatively few appear to have formed from the Permian to the Lower Cretaceous. A new peak was reached during the Upper Cretaceous and Paleocene, particularly in the Mediterranean bauxite belt, followed by minor formation during the Oligocene. Large quantities of Karst bauxites were formed during Miocene and Pliocene on some islands of the Caribbean. Quaternary and Recent Karst bauxite formation is restricted to a few islands in the West Pacific (Weisse, 1976).

The intensity of bauxite formation with respect to time is summarized in Figure 2.

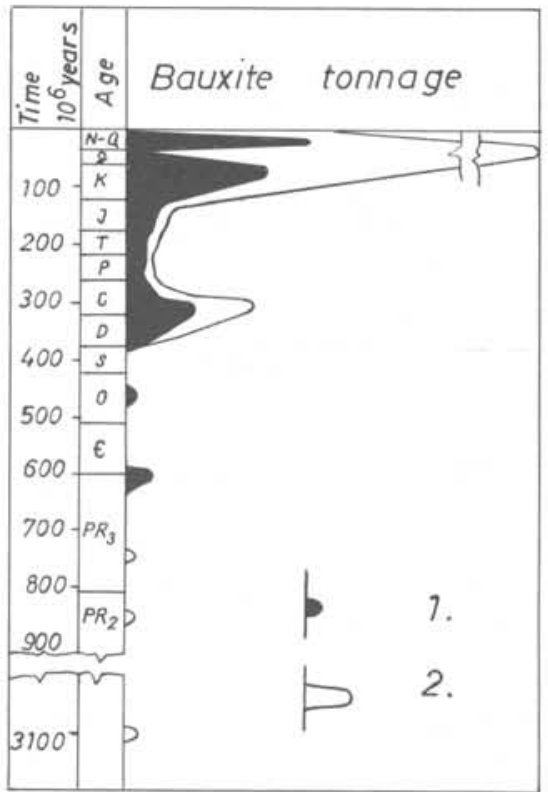

Figure 2. Intensity distribution of bauxite formation in time 1. Karst bauxites 2. Lateritic bauxites

\section{Chemical Composition}

Bauxites are characterized by a combined enrichment of Al, $\mathrm{Fe}$ and $\mathrm{Ti}$, compensated by a depletion in $\mathrm{K}, \mathrm{Na}, \mathrm{Ca}, \mathrm{Mg}$ and $\mathrm{Si}$. High grade bauxites contain generally $40-60 \% \mathrm{Al}_{2} \mathrm{O}_{3}, 10$ to $25 \% \mathrm{Fe}_{2} \mathrm{O}_{3}$ and $2-5 \% \mathrm{TiO}_{2}$. There exist some low iron white and grey bauxites too, containing less than $5 \% \mathrm{Fe}_{2} \mathrm{O}_{3}$ with as much as $70 \% \mathrm{Al}_{2} \mathrm{O}_{3}$. In a few deposits $\mathrm{TiO}_{2}$ can be as high as $10-20 \%$.

Some trace elements - such as $\mathrm{Be}, \mathrm{Cr}, \mathrm{Ga}, \mathrm{Ni}, \mathrm{V}, \mathrm{Zr}$ - are generally enriched in bauxites; others, however, are depleted (for example: $\mathrm{Rb}, \mathrm{Pb}, \mathrm{Sr}, \mathrm{N}$ ).

\section{Mineralogical Composition}

More than 170 minerals have been identified so far in bauxites, but only ten of them occur in rock-forming quantities, namely: gibbsite, boehmite, diaspore, corundum, goethite, hematite, kaolinite, halloysite, anatase, rutile.

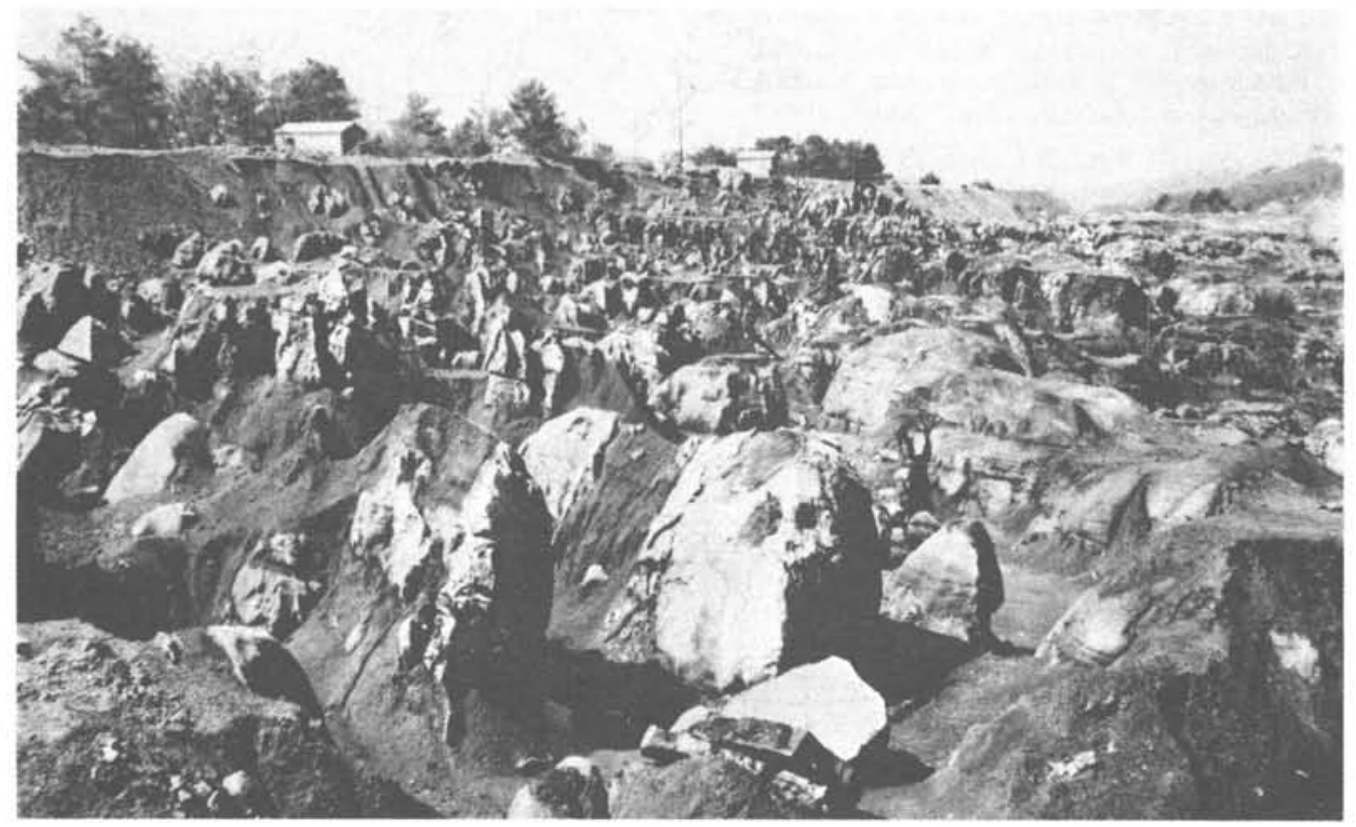

Bauxite deposit in France: karstified surface of footwall limestone ("Bauxites du Midi", 1956). 
Gibbsite is the main alumina mineral of Lateritic bauxites. In Karst bauxites, gibbsite, boehmite and diaspore are present in relatively similar abundance. The Quaternary and Tertiary deposits are mainly gibbsitic, the Mesozoic ones boehmitic, while the Paleozoic ones are diasporic. Metamorphism changes the initial mineralogical composition of the given bauxite deposits from gibbsite to boehmite, diaspore, and at higher grades, to corundum (emery).

A significant discovery was the detection of microcrystalline corundum in some Lateritic and Karst bauxite deposits that have never been buried or affected by tectonic stresses. This corundum is concentrated mainly in the ooids and pisoliths of the bauxite and was formed under surface conditions by diagenetic processes (Beneslavsky, 1974).

\section{Origins}

Bauxites and laterites are products of surface weathering. Bauxite formation at depth, below a thick overburden, is impossible and no bauxites can be formed at the bottom of the sea. The main factors affecting bauxite formation are as follows:

1. Climatic conditions: Mean annual temperature - around $26 \mathrm{Co}$; annual rainfall - 1200 to $4000 \mathrm{~mm}$; number of rainy months - 10 to 11 ; number of dry months - 1 to 2 . (This corresponds to a tropical monsoon climate).

2. Vegetation: Generally between a tropical forest and a savannah zone; microorganisms probably play an important role in decomposing the minerals of the parent rock and in buffering the $\mathrm{pH}$ of the percolating ground water.

3. Geomorphology: Gently undulating land surfaces where surface erosion and detrital sedimentation are insignificant.

4. Hydrogeology: Weathering profile must be above the ground water table or at least above its minimum level; below, leaching becomes very slow or stops entirely; good drainage is indispensable for formation of bauxite.

5. Physico-chemical conditions: In lateritic profiles the $\mathrm{pH}$ of the ground water is neutral or slightly acidic and the water itself is strongly unionized. In karst environment, ground water percolating through the bauxite is generallly slightly alkaline and contains dissolved alkali earth ions. The higher the temperature of the groundwater, the more intense the leaching. Oxidizing conditions are favourable for bauxite formation; slightly reducing conditions result in a much slower formation rate.

6. Parent rock composition: Under favourable conditions practically all rocks undergo lateritization but the speed of the process varies. High porosity and permeability of the parent rock are favourable, combined with a low surface stability of its minerals. High initial alumina and low silica content are especially favourable for the formation of high grade bauxites.

7. Time factor: Lateritization is considered to be a very slow process, taking some 1 to $5 \mathrm{Ma}$. Recent theoretical calculations (Fritz and Tardy, 1973) combined with field observations show that under favourable conditions entire bauxite deposits could have been formed during a few hundred thousand years.

\section{Other Particulars}

The formation of Lateritic bauxite deposits is basically an eluvial, in-situ process. Both direct and indirect formation of bauxites have been recognized (Balkay and Bardossy, 1967). In the first, minerals of the parent rock are weathered directly into alumina and iron hydroxide minerals by a very intense leaching of all alkalies, alkali earths and silica. In the latter case, the initial alumosilicate minerals are weathered first into clay minerals; these are then decomposed during a second stage of the weathering. Indirect formation is a less intense process and takes more time. While the two processes may occur in geographically separate areas, they can commonly be observed in the same deposit as well.

Karst bauxite formation always involves one or several reworkings of the primary weathering products. This is why, in most cases, the question of the parent rock is difficult to resolve. Some researchers regard the underlying carbonate rocks as unique parent material (Weisse, 1976); others prefer lateritic weathering products of alumosilicate rocks (Bushinsky, 1975). Still others opt for windblown volcanic ash scattered on the surface of carbonate rocks (Comer, 1974). It seems probable that several parent materials contributed in different percentages to the accumulation of any Karst bauxite deposit.

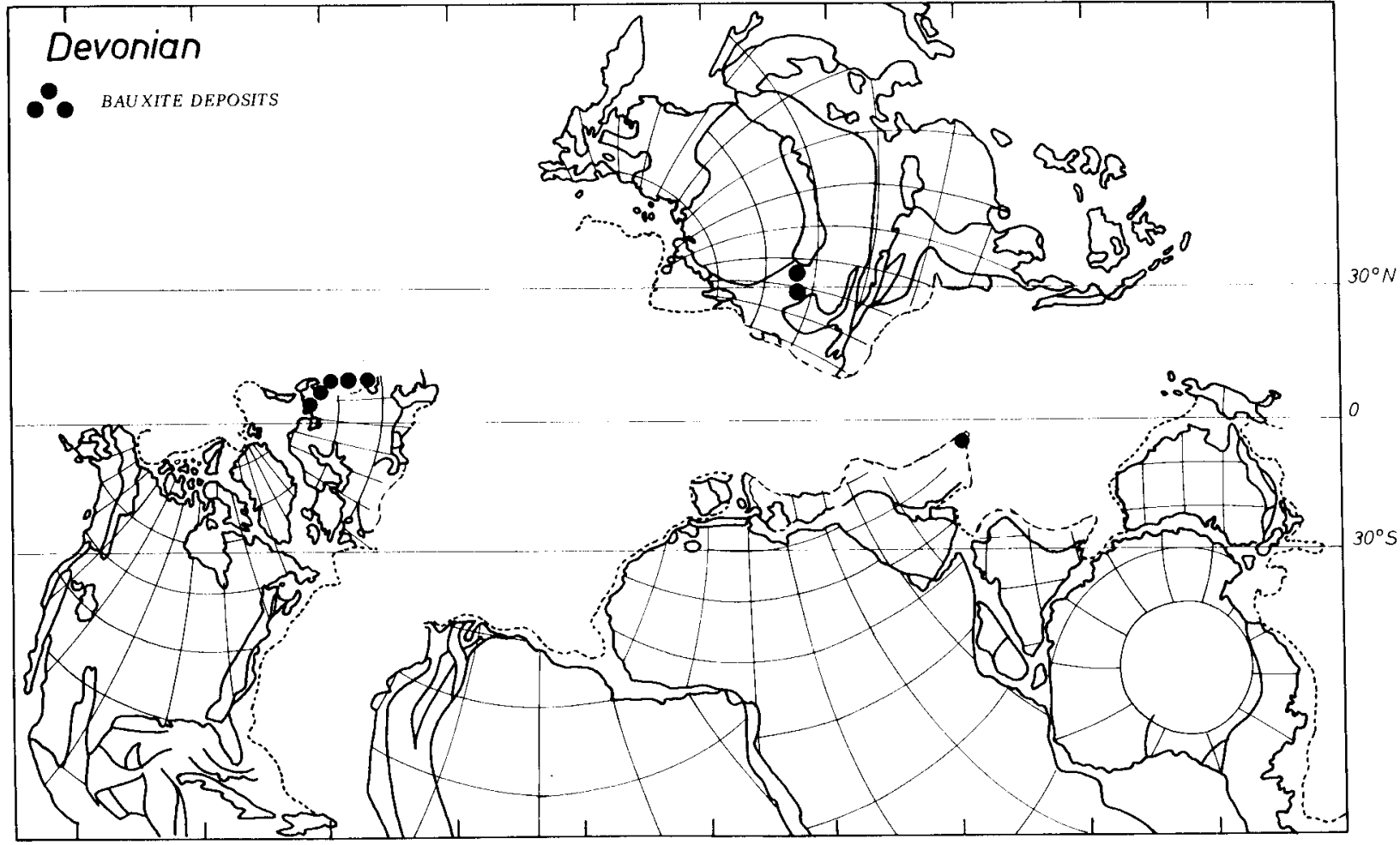

Figure 3. Distribution of bauxite deposits during Devonian. 


\section{Geotectonic and Paleogeographic Significance}

Formed under well defined morphological and climatic conditions, bauxites and laterites may be used in paleogeographical and paleoclimatological reconstructions.

The climatic conditions of bauxite and laterite formation are currently satisfied only between the latitudes $30^{\circ} \mathrm{N}$ and $30^{\circ} \mathrm{S}$. But Mesozoic bauxites extend to $60^{\circ} \mathrm{N}$ and the Paleozoic ones even to the $770 \mathrm{~N}$ - beyond the Arctic circle - as, for example, on the Taymir Peninsula in the U.S.S.R.; yet within Phanerozoic time, climatic conditions allowing bauxite formation never surpassed $55^{\circ}$ latitudes.

A satisfactory explanation can be obtained only by changing the mutual position of the continents, that is, by accepting the concept of continental drift (Bárdossy, 1973). Reconstructions of Smith, Briden and Drewry (1973) for all Phanerozoic periods have been completed by the author. Figure 3 shows the reconstruction of continents for the Devonian period, and the distribution of bauxite deposits within the required climatic zone.

Intensity of bauxite formation with time is now thought to have been related to the global radiation balance. Recent measurements from meteorological satellites indicate that the ratio of adsorbed and reflected solar energy (radiation balance) is markedly different over oceans and continents and varies also with latitude. Continental drift must have led therefore to changes in the global radiation balance. Unpublished calculations of Hungarian meteorologist $Z$. Dobosi reveal that the global radiation balance had maxima from the Devonian to Lower Carboniferous and during the Mesozoic; since the Eocene the balance has gradually decreased to its present level.

One may conclude, therefore, that the development of bauxites was controlled by the extent of the favourable climate zone, which varied according to the global radiation balance and other climatic factors.

\section{International Scientific Cooperation}

The study of bauxites has been highly dependent on international cooperation. Future progress will rely even more on mutual exchange of information through such activities as the following:

- The International Committee for the Study of Bauxites and Alumina (ICSOBA), founded in 1964 in Zagreb, Yugoslavia, provides an ongoing forum for exchange of scientific information amongst bauxite geologists, mining engineers and technologists. Congresses have been held in Zabreb (1964), Budapest (1969), Nice (1973), and Athens (1978) (see EPISODES, Vol. 1978, No. 4, p. 35). ICSOBA publishes a scientific journal under the name "Travaux de l'ICSOBA";

- The IGCP Project No. 129 - "Lateritization processes" accepted in 1975 and currently under the leadership of Dr. P.K. Banerji (India), includes a 13-member international working group, as well as national correspondents from 21 countries. The project aims to develop an inventory of the major laterite occurrences of the world, to coordinate laboratory studies and genetic research;

- The International Association of Geochemistry and Cosmochemistry (IAGC) which in 1973, organized a working group devoted to "Geochemistry of supergene cycles in humid tropical climates: laterites and lateritization", under the chairmanship of Dr. J. Goni (France). The aim of this working group is to promote geochemical studies of laterite profiles.
The fact that these international scientific bodies have directed their attention to bauxite research underlines the growing recognition of the scientific and economic significance of bauxites.

\section{References}

Aleva, G.J.J., 1975, The bauxites of the Guyana Shield as a source for refractory grade raw materials: Interceram, Nr. 4, p. 259-261.

Balkay, B. and Bardossy, Gy., 1967, Étude des processus élémentaires de la latérisation sur latérites guinéennes: Bull. Hungarian Geol. Soc., Budapest, v. 97, p. 91-110.

Bárdossy, Gy., 1973, Bauxite formation and plate tectonics: Acta Geol. Acad. Sci. Hung., Budapest, v. 17, p. 141-154.

Beneslavsky, S.I., 1974, The mineralogy of bauxite: Moscow, Nedra Publishing Co., 166 p.

Bushinsky, G.I., 1975, The geology of bauxite: Moscow, Nedra Publishing Co., 145 p.

Coetzee, C.B., 1940, Sillimanite-corundum rock; a metamorphosed bauxite in Namaqualand: Trans. R. Soc., South Africa, v. 28, p. 199-205.

Comer, J.B. 1974, Genesis of Jamaican bauxite: Econ. Geol., v. 69 , p. $1251-1264$.

Fritz, B. and Tardy, Y., 1973, Étude thermodynamique du systeme gibbsite, quartz, kaolinite, gaz carbonique; application a la genese des podzols et des bauxites: Sci. Géol. Bull., v. 26, p. 339-367.

Greig, E.W., 1977, Trombetas and other Amazon bauxites, Brazil: Soc. Min. Eng., AIME, Preprint 77-H-92, p. 1-34.

Hunter, D.R., 1962, The mineral resources of Swaziland: Swaziland Geol. Surv. and Mines Dept., Mbabane, 111 p.

Kirpal, G.R. and Teniakov, V.A., 1978, The ore deposits of aluminium, in Ore deposits of the U.S.S.R.: Moscow, Nedra Publishing Co., p. 262-345.

Lotze, J., 1978, Economic evaluation of world bauxite resources: in Proc. of the 4 th Int. Congress of ICSOBA, Athens, v. 2, p. 493-506.

Michailov, B.M. 1977, Evolution of surface ore formation during the history of Earth, in Problems of lithology and sedimentary ores: Moscow, Nauka Publishing Co., p. 179-184.

Sidorenko, A.V. and Teniakov, B.A., 1976, Bauxite formation in the history of Earth and the concept of analogy for surface processes during Precambrian and Phanerozoic: Dokl. Akad. Nauk. U.S.S.R., v. 226., p. 1150-1153.

Smith, A.G., Briden, J.C. and Drewry, G.E., 1973, Phanerozoic world maps: Spec. Papers in Palaeont., v. 12, p. 1-42.

Valeton, 1., 1972, Bauxites: Elsevier Scientific Publishing Co., Amsterdam, 226 p.

Weisse, G. de, 1976, Bauxites karstiques sur calcaires récents: Travaux de l'ICSOBA, Zagreb, No. 13, p. 51-62.

ABOUT THE AUTHOR: Currently chief geologist of the Hungarian Aluminum Corporation, Dr. György Bárdossy has worked as a field geologist in bauxite prospecting, as mineralogist and geochemist in the Geochemical Laboratory of the Hungarian Academy of Sciences.

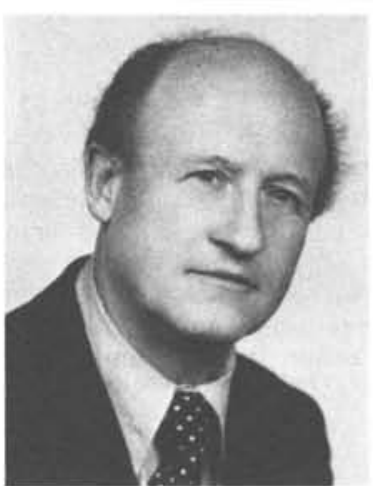

